\title{
The Civility of Scholars
}

The Civility of Scholars: A case for open access to historians of the files in the editorial offices of the projects for the publication of the papers of major historical figures.

F REe ACCESS, NOT ACCESS DENIED, is the right policy for all of us. Librarians, archivists, and historians have a common task. We seek to make the past accessible to ourselves and to others who want to know it better. Free access to all the materials of history should be our goal. This includes the need for historians to work in the files of the editors of the collected works of presidents and other major political figures.

It is easy for a historian to take this unequivocal position. The magnificent assistance I have had from people like Sara Jackson in the National Archives before she joined the National Historical Publications Commission and Richard Harwell when he was librarian at Bowdoin is all the documentation this historian needs to acknowledge, with thanks, the importance of free access to the writer of history.

I contend, moreover, that the letterpress editors could make an equally strong case for free access. As scholars we work much of the time in a quiet and even lonely way but we do so, partly at least, because we think that the things of the past, with which we spend so much of our lives, are important to the public. I am not so naive as to fail to recognize the strain put on an archivist or an editor when a pretentious senior historian or a brash fledgling arrives to disrupt the day. But, the difficulties of attending to such types acknowledged, I contend the invasion of historical priva- cy is what, in the last analysis, we all seek to accomplish. We want to know as much as is possible about men so important that neither they nor other men of their era can be known without knowing what they said. The point of the letterpress editions is, after all, to make available the whole of the writings of men who have made a critical difference in our history. To collect these works the editors, who are both historians and research librarians-they illustrate perfectly how connected all our work ishad the help of archivists across the country. They should count on the help of historians as well when doing their collecting.

Due in part to a laudable insistence on accuracy, some editors and editorial boards have not been willing to grant free access to the collection prior to publication. This is an understandable position but since editions of collected papers can take decades to complete, there is the real possibility that myths about the man whose papers are being edited will persist. A historian has to use the best existing assemblage of the writings of the particular important historical figure in question if his picture is to be a true one. Free access is needed.

To grasp the principle of free access we must first examine the practical problems that might make it untenable. The editors of "The Collected Letters of ..." have the job of locating all items, getting these photocopied, filed, and then print- 
ed. The standards of editorial accuracy are exceedingly high and most editors have taken on the added responsibility to identify in notes every person and event other than the obvious. In order to do this some, but by no means all, editors claim that they must refuse access to scholars who would like to see their files while the editing is under way. Editors assert that the intruding historians would (1) impede the efficient discharge of the editorial responsibilities and (2) violate agreements of restricted access made with donors of letters. Restricted letters are filed with the bulk of nonrestricted material and it would be a costly task to prevent their use by readers of the complete files.

These problems are understandable to specialists in the field. We want and need the splendid annotated volumes of letters with the editorial finesse we have come to expect of them. But I contend that if, as scholars, we have accuracy as one of our goals, we cannot wait for these long-term projects to be completed before permitting access to the collections.

Let me illustrate this by being autobiographical. I am interested in Ulysses S. Grant. Don't ask me why; I won't know until I get the book written. But certainly one reason why is the immediate curiosity $\mathrm{I}$ have as a historian and a citizen in the relationship in the United States between the military and the government-in the connection between the waging of war and presidents. I think I can make a plausible case that with the possible and interesting exceptions of George Washington and Dwight Eisenhower, there was no American heropolitician who better illustrates the ambiguous attraction of Americans to warriors than Grant.

But this is an obvious op-ed page kind of observation. To say something useful about a subject I consider important I need a great deal of evidence. The questions raised by my speculations are complex ones. They involve social, economic, political, military, and psychological aspects of a life over its entire span. To get answers I need to know much about the men who were close to Grant and observed him in war and in peace. For this I must do the usual archival research, reading, for example, the papers of the men on his military staff and cabinet that are in the Library of Congress.

But ultimately, I need to get to Grant himself. And what I want is John Simon's magnificent collection of the general's papers. I can turn to page 85 of volume one and read Grant writing to his wife in 1846 during the Mexican War: "Although the balls were whizing [sic] thick and fast about me I did not feel a sensation of fear until nearly the close of the firing a ball struck close by me killing one man instantly, it nocked [sic] Capt. Page's under Jaw entirely off and broke in the roof of his mouth, and nocked Lt. Wallen and one Sergeant down besides, but they were not much hurt. Capt. Page is still alive." And to continue with his account of the battle of Palo Alto I can read: "It was a terrible sight to go over the ground the next day and see the amont [sic] of life that had been destroyed. The ground was litterally [sic] strewed with the bodies of dead men and horses."1

All right. There we have the general reflecting on war at an early date. Move up to the Civil War. What did he have to say at the time of his face-off with Lee when wounded men of Cold Harbor were left in agony on the field for two days. I reach for a letter dated 7 June 1864 but unfortunately John hasn't gotten there yet. A lifetime of letters has been collected since the project began in 1962 but the published letters have only reached 5 April 1862 in volume four. ${ }^{2}$ The letter I want will be in perhaps volume ten or eleven. And what 
about the general's reflections on war when he met with Bismarck in 1878? What volume will that be in?

Very well. No definitive printed source exists for the later period. Therefore, go to the archives and read the originals. This is the way historians normally work. Perhaps there I can find Grant on Cold Harbor and on Bismarck's Berlin. I can locate the two letters I need; I don't have to wait for their publication.

The trouble with this procedure is that history is such complex business. It deals with people. Historians do not go point by point logically leaping time to find crystal clear observations on a given question at various steps in a man's career. The man one is looking for is not indexed yet; at least not for the questions a newly curious historian is asking. The scholarship of history and of biography is a scholarship of saturation. Somehow, despite ultimate unattainability, history demands completeness.

As a historian, I try to be complete; I track General Grant to an archive in Iowa. The archivist looks at me as if I am hopelessly naive and explains that I should be in Carbondale where copies of all Grant items were long since sent. I explain that I was denied access. He shakes his head wondering why he went to the trouble of photocopying all those pieces of papers and brings out the boxes of the originals. I dig in.

However, even if all the digging in all of the Iowas does approach completeness, no specialist in the field will have full confidence in my printed page without reference to the definitive collection at the Grant Association. The critic will ask why I have ignored the most reliable source of my subject's letters. I know that if I were reading a book about a man whose papers were being published and the author did not use the work of the scholars who carefully collected all the letters I would be skeptical as to how authoritative the book could be.
Multiarchival research is fun; I happen to love it-I recently ran across again Samuel Eliot Morison's good story about the historian who writes one lame paragraph, dawdles through a second, and then in the third, discovers the need for a fact. Joyous he runs to an archive, has fun and feels virtuous, and escapes from having to write his paragraph. But has the scholar working on a man whose collected works are being published the liberty to enjoy such innocence? Can he pretend that the Madison or Webster papers are not being published or filmed and go on about his own search of many archives already culled of such items? Of course he can try but his critics will not permit him his fantasy.

Any serious reader would know that the definitive editing of the papers was going on. That reader would expect of the scholarly world sufficient cooperation that he could be assured that any piece of historical writing worth his attention was built on the sturdiest of research foundations. And, clearly, the letterpress projects meet that test of sturdiness splendidly.

The person who makes the most sense about this problem is Elting Morison, a scholar who has been on both sides of the fence. And he sees no need for the fence being there. Morison was the editor of the Theodore Roosevelt Papers and the author of a splendid biography of Henry L. Stimson. In his view, the letterpress editions on one hand and biographies on the other "have a totally different utility." ${ }^{3}$ Biographies and monographs based on the letters will come and go but with the rare exception of a letter incorrectly attributed or an annotation in need of correction the letters published according to the standards of the projects we are discussing today will stand as definitive.

Precisely because these editions command so much authority, the presentday work of historians should neither 
depend on less reliable and less complete sources than the files of the collected works nor on waiting perhaps fifteen years for the completion of their publication. When Morison was editing the Roosevelt Papers, the editors made copies of letters available right in the editorial shop to such writers as Carlton Putnam. In Morison's view, there is no fundamental competition between letterpress publications and the work of historians who use the letters. ${ }^{4}$

There are, I believe, two other reasons beyond efficiency impairment and restrictions by donors why the editorial boards are reluctant to have historians in their files. One is that the project will be scooped if a hitherto unknown group of letters is used by a historian before the letters reach publication in chronological order. The other is the sense that the editorial boards are somehow the keeper of the only correct memory of the man whose works they are publishing.

With respect to the first, I have no trouble putting myself in an editor's shoes and imagining the pride I would have if I uncovered a rich vein of letters.

I wonder, however, if we don't make too much of the problem of a scoop. Every now and again the New York Times carries an item about some historical find that exposes an eminent man by uncovering long-lost letters. These usually involve an old-fashioned sin like sex and there is a brief flutter of nostalgic interest. How often, however, does this kind of expose, in which one scholar may have scooped another, compare in importance with the whole of the work of either an editor or a historian? Indeed the very nature of the letterpress publication projects, the presentation of all of a man's words, is predicated on the need to rescue an important figure from the distortions possible when too much is made of matters of small moment.

On the second point, I have no diffi- culty imagining how the members of an association charged with the responsibility of publishing the collected works of a man or woman would come to have a protective feeling. You cannot help feeling close to someone with whom you work for as long as the editors do with their particular man. The editors fear a marauding historian who will come in and butcher the memory of a man to whom they have committed so much of themselves. I think the only answer is that this is a risk the editors must take. Butchers there are but I can only believe the destruction will be greater if they are denied the chance to learn as much as they can about the man from the complete files of his letters. And here again I would invoke my trust in the fraternity of scholars; editors, archivists, librarians, and historians do have a common bond. I doubt if all the users will be butchers. To be sure there are shabby books, but there is also John Clive's Macauley. Editors are not alone in wanting their man honorably-and honestly-handled.

To turn from my personal remarks about Grant and speak about a more recent general, I would like to mention a talk I had with Alfred D. Chandler, Jr., who was until recently the editor of the Eisenhower Papers. Attractively, I think, General Eisenhower was exceedingly open about his papers; his view was let the words speak for themselves. In fact so committed was Eisenhower to this concept that while he was alive he made the Pentagon uneasy because he was sometimes critical that certain papers were categorized as Top Secret. This categorization does require researchers to get clearance, which I am told is not hard to obtain (and, of course, is irrelevant to eighteenth- and nineteenthcentury collections). In Chandler's view both as a historian and as an editor there is no reason why, if historians are willing to stay out of the way of the particular papers being edited at the moment 
and obey restrictions established by donors or by national security requirements, they should not work in the files while papers are being published. And if this principle is sound for a man as recent as Eisenhower, many of whose correspondents are very much alive, it is certainly sound for figures dead a hundred or two hundred years. ${ }^{5}$

What Mr. Chandler and Mr. Morison and in fact General Eisenhower were counting on is the civility of scholars. There is an argument for free access based on the fact that most of the letterpress compilations are, in large measure, paid for with tax revenues and are, therefore, in the public domain. ${ }^{6}$ I am persuaded, however, that what we gain as cooperating scholars is a more compelling reason for open access than the legal point. Historians should lend support to the research activities in the libraries on their campuses and in the public archives. They should follow the lead of research librarians and help in the collection of documents for the letterpress projects. When it comes to using the product of this searching once it is in the files of "The Collected Works of ..." civility is the key to the question of access.

A scholar seeking to work in the files of a project should be expected to have a serious and defined need to use the collection. He should be expected to honor house rules of operation and not impede the efficiency of the editorial process. He should be told about those letters that have been given with restriction and agree not to use such material. (And shouldn't we discuss ways to discourage such restrictions?) In short, historians and research librarians and archivists and editors can sit down and work out ways to work so that each can get his work done.

I suppose I should not claim too much for my profession or for yours but I am willing-indeed eager-to claim a good deal for both. The scholarly world is quite as much the real world as is the world of the politician or the warrior or the construction worker or the gambler. All of us in this room have the great fun of taking the disparate pieces of written knowledge of our civilization and, as they say of poets, making the words work. One small sign of a better present than that of the paper shredders would be for scholars to set an example of free access to all the writings that important men have left. Only by setting the words of the past to work have we got even a fighting chance of making an acceptable present. We can do this only with a civil regard for each other's different but compatible tasks. We should help each other because there is so much work to do.

\section{References}

1. John Y. Simon, ed., The Papers of Ulysses S. Grant (vol. 1; Carbondale: 1967), p.85.

2. Ralph G. Newman, "Foreward," in John Y. Simon, ed., The Papers of Ulysses S. Grant (vol. 1; Carbondale: 1967), p.xii.

3. Elting Morison in conversation with the writer, June 1973.

4. An interesting example of a book making use of a collection of letters long before their chronological publication is ClaudeAnne Lopez, Mon Cher Papa (New Haven,
1966). Her book is also an example of an "in-house" book and raises the question of selective access of privileged scholars. [A section of this paper on these subjects, deleted in the interest of brevity, is in my files. WSM.]

5. Alfred D. Chandler, Jr., in conversation with the writer, June 1973.

6. College and Research Libraries News 34:148 (June 1973); American Historical Association Newsletter 11:51-52 (May 1973). 